\title{
THE EFFECTIVENESS OF NON-FORMAL PHYSICAL EDUCATION CURRICULUM FOR THE PHYSICAL DEVELOPMENT OF 11-13-YEAR-OLD CHILDREN
}

\author{
Asta Šarkauskienė, Antanas Lukoševičius, Bronė Švitrienė \\ Klaipèda University, Klaipéda, Lithuania
}

\begin{abstract}
Background. This study aims to develop and implement a curriculum of non-formal physical education in school and assess its effectiveness for the physical development of 11-13-year-old children.

Methods. The research was conducted in two stages. In the first stage $51 \mathrm{fifth}$ grade children ( $M_{\text {age }}=11.3$ years) participated in a quasi-experiment for two years. The children were organized into two groups: $\mathrm{E}$ and $\mathrm{C}$. Both groups shared the duration ( 1 hour) and frequency (twice a week) but were different in their education curriculum. In the second stage (after four years) 72 sixth graders $\left(M_{\text {age }}=13.0\right)$ participated from the same comprehensive schools. The focus groups underwent anthropometric (height, weight, BMI) and physiometric (VC, right and left handgrip strength) measurements. Dependent $t$ test indicated that over two years $\mathrm{E}$ and $\mathrm{C}$ group girls' and boys' height, weight, right and left handgrip strength indices increased significantly, $p<.05$.

Results. E group girls' and boys' BMI and C group girls' VC indices did not change significantly, $p>.05$. Independent $t$ test indicated that in the second research stage differences in anthropometric and physiometric measurements of groups were not significant, $p>.05$.

Conclusion. The developed and implemented curriculum of non-formal education in the schools had the biggest positive effect on the decrease of 11-13-year-old children's levels of BMI and the increase in the VC levels.
\end{abstract}

Keywords: 11-13-year-old children, non-formal physical education, physical development.

\section{INTRODUCTION}

$\mathrm{P}$ hysical development is the process of continuous change that occurs in the body, starting with conception and continuing through adulthood (Wilmore \& Costill, 2004). The general postnatal biological development is very similar, however big differences dominate between individual morphological and functional indices, which are influenced by many factors - biological (genetic, sex, health condition), cultural, geographical position, environmental, etc., though the most important are genetic and environmental (Abernethy et al., 2013; McArdle, Katch, F. I., \& Katch, V. L., 2009; Machado, Filho, \& Fernandes, 2008). One of the environmental factors is education (formal and non-formal) process. Some physical development indices are more determined by environment, the other by genetic factors.

The genetic determinism of the human organism particularly manifests through morphogenesis. In the research of twins, parents and brothers and sisters, the big impact of genetic factors for height indices was ascertained. According to the data of Malina, Bouchard, and Bar-Oro (2004), about $60 \%$ or more height indices are related with genotype. The research of height of children engaged and not engaged in sport and the obtained results prove that physical activity has minimal or does not have any influence to changes in height (Baxter-Jones, Eisenmann, Mirwald, Faulkner, \&Bailey, 2008; Erlandson, Sherar, 
Mirwald, Maffulli, \& Baxter-Jones, 2008). Very tight interaction of genetic and environment factors burden the estimation of their influence on body weight (McArdle et al., 2009). It is a negotiable question how genetic factors affect weight indices. The scientists carrying out research in genetics (Haberstick, et al., 2010; Maes et al., 2009; Malina et al., 2004) point out that this index is hereditary from 30 to $70 \%$. However, the body weight varies more because of the lifestyle habits and social, economic, cultural and other factors (Bouchard \& Katzmarzyk, 2010; California Department of Education, 2009).

Analyzing the factors that influence physiological indices it was determined that lung vital capacity is more conditioned by genetic factors, though muscle power - by environment factors (Malina et al., 2004; McArdle et al., 2009).

The empirical research suggests that 11-13-year-old children's physical development indices frequently do not match the development standards established for children at this age. In their longitudinal research Julia, Van Weissenbruch, Prawirohartono, Surjono and Delemarre-van de Waal (2008) and Roustorp (2010) estimated that the weight of children at this age increased during the last years. According to Gao, Oh and Shehg (2011), a fifth (20.5\%) of 11-yearold children were overweight, though $23.7 \%$ obese. Tutkuvienè (2005) has been investigating children's development for many years. The scientist determined that during the last decades the indices of 11-13-year-old Lithuanian children's power and lung vital capacity increased largely. The aforementioned facts encourage searching for the means which would motivate the harmonious physical development of children at this age.

One of the ways to solve the problem is the education of harmonious physical development in a non-formal way. Through non-formal physical education (NFPE) in school pedagogues have the power to make daily physical activity accessible and engaging for every child and to help all youths in after school programs to discover the benefits and joys of physical activity. NFPE in school programs give children the opportunity to develop further the skills taught during the regular school day. As some children do not receive daily physical education during the regular school day, after school programs may be the only place where the students can regularly engage in physical activity and to seek balanced physical development (California Department of Education, 2009)

Research by Carrel et al. (2011), Da Silva, Fisberg, de Sousa Pires, Nassar, and Sottovia (2013) demonstrates that NFPE curriculum in school can improve body composition. Drake et al. (2012) conducted telephone surveys with 1718 high school students and their parents. The scientists estimated that team sport participation had the strongest and most consistent inverse association with weight status. Vajda et al. (2007) carried out research during which 10-year-old obese boys not only participated in physical education lessons, but also took part in three NFPE sessions of $60 \mathrm{~min}$ time in the afternoon, on Mondays (swimming and water games), Wednesdays (folk dance) and Fridays (soccer). Anthropometric and physiometric data were collected. Relative body fat content and BMI did not increase during the observation period in contrast to the significant increase in the control group. Peak minute ventilation, aerobic power, oxygen pulse increased in the study group and did not change in the control group.

In present study the following research question was formulated: What curriculum of NFPE in school can positively affect physical the development of 11-13-year-old children?

The aim of this study was to develop and implement a curriculum of non-formal physical education in school and assess its effectiveness for the physical development of 11-13-year-old children.

Research hypothesis: training 11-13-yearold children's physical development, when the individualized non-formal education curriculum is implemented combining and integrally developing knowledge, abilities, attitudes and using the methods and forms that activate the child, has a positive effect on their physical development.

\section{METHODS}

Participants. The research was conducted in two stages. In the first stage (academic years 2007-2009), 51 fifth grade children $\left(M_{\text {age }}=11.3\right.$ years, $S D=0.26,50.2 \%$ boys), who took part in NFPE in school for the first year, from four Klaipeda city (Lithuania) schools were selected to participate in a quasi-experiment. They were assigned to one of two groups. Criterion assignment strategy was used: children from two schools were assigned to 
the experimental group (E, $n=29.0 \%$ boys) and children from two other schools were assigned to the control group (C, $n=22.0 \%$ boys) and they participated in NFPE permanently for two years.

In the second stage (academic year 2012-2013) the participants were 72 sixth graders $\left(M_{\text {age }}=13.00\right.$ years, $S D=0.33 ; 52.4 \%$ boys) who took part in NFPE in school for the second year, and they were from the same schools who participated in the quasi-experiment (Group I $-n=46$, Group II $-\mathrm{n}=$ 26) (see Figure 1).

Written voluntary informed consent was provided by all of the children and their parents and/or foster parents. Department of Physical Education (Klaipeda University) approved the study.

Instruments. In the first stage at the beginning (2007-10), in the middle (2008-05) and at the end (2009-05) of the quasi - experiment the focus groups conducted anthropometric and physiometric measurements.

Anthropometric measurements. Height was measured using roller height meter (Seca, model 206, Germany). The height meter was mounted on the wall and the participants stood erect, barefooted, and looked straight ahead. Before being measured or weighed, children were asked to remove their shoes and outer clothing, such as jackets. Students were asked to stand with their backs and heels against a wall that had a measuring tape attached. A measuring triangle was placed on the children's head, forming a right angle with the wall. Height was measured to the nearest half centimetre from the lower edge of the triangle. Weight was measured to the nearest 0.1 kilogram using a calibrated scale (Seca, model 709, Germany) that was zero balanced before each student was weighed. Body mass index of the participants were calculated from their respective height and weight using the relation $=$ Weight/Height ${ }^{2}$.
Physiometric measurements. Vital capacity was defined as the volume of air delivered during expiration starting from full inspiration and completed while the children were as relaxed as possible while completing the expiration. Vital capacity was measured using a portable spirometer (Spirotest, model Rudolf Riester $\mathrm{GmbH})$. The maximal handgrip strength was measured using a hydraulic hand dynamometer (Seahan, model SH5001). All participants were examined in a standardized position (Skernevičius, Raslanas, \& Dadeliene, 2004): the subject holds the dynamometer in the hand to be tested, with the arm at right angles and the elbow by the side of the body. The width of the handle is adjusted for the participant's hand size. When ready, the subject squeezes the dynamometer with maximum isometric effort, which is maintained for about 5 seconds. No other body movement is allowed. The best result of the right and left hands was chosen for the analysis. The presented scores are expressed in kilos force.

During the second stage the children of six grades performed the same measurements as their colleagues four years ago.

After applying document analysis method, the average of children age was determined. The age average was 11.3 years during study I, 11.9 years during study II, 12.9 years during study III and 13.0 years during research in stage II. Evaluating the young adolescents' physical development, we compared the averages of anthropometric and physiometric indices with the average means of the same age children's anthropometric and physiometric indices given by Tutkuviene (1995) and Tutkuvienè and Jakimavičiene (2004). We compared the study I physical development indices with 11-year-old children's indices, study II indices with 12-year-olds' indices, and study III indices with 13-year-olds' indices. The II stage research

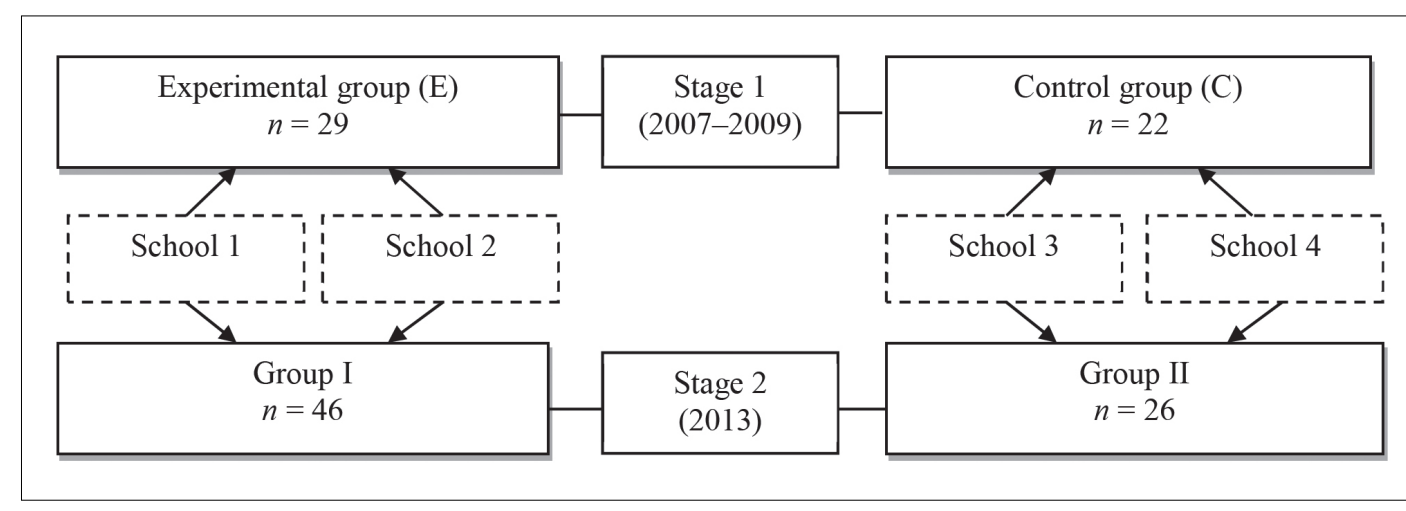

Figure 1. Distribution of children who participated in the research 


\begin{tabular}{|c|c|c|}
\hline $\begin{array}{l}\text { Table } 1 \text {. Content and its } \\
\text { percentage distribution }\end{array}$ & Experimental group & Control group \\
\hline $\begin{array}{l}\text { control groups' NFPE at } \\
\text { school }\end{array}$ & $\begin{array}{ll}\text { 1. } & \text { Knowledge }(10 \%) \\
\text { 2. } & \text { Cooperative games }(40 \%) \\
\text { 3. } & \text { Sports games }(10 \%) \\
\text { 4. } & \text { Athletics }(8 \%) \\
\text { 5. } & \text { Gymnastics }(10 \%) \\
\text { 6. } & \text { Fun outdoor activities }(7 \%) \\
\text { 7. } & \text { Sport and wellness activities }(15 \%)\end{array}$ & $\begin{array}{l}\text { 1. Knowledge (4\%) } \\
\text { 2. Technical and tactical skill development for } \\
\text { game "Quadrate" }(30 \%) \\
\text { 3. Technical and tactical skill development for } \\
\text { relay race "Brave, strong, quick" }(30 \%) \\
\text { 4. Athletics, "Triathlon" }(20 \%) \\
\text { 5. General physical fitness and relay race }(10 \%) \\
\text { 6. Competitions }(6 \%)\end{array}$ \\
\hline
\end{tabular}

results were compared to average values of 13 -yearold Lithuanian children.

Procedures. After being informed about the nature and steps of the study and agreeing to participate, the young adolescents were invited to attend the two-year quasi-experiment. NFPE in school were held at the end of formal education. Both experimental and control groups shared the duration (1 hour) and frequency (twice a week) but were different in their education programs.

Experimental group (E) worked under the program developed by us. $85 \%$ of NFPE content was formed of sessions and $15 \%$ - sport and wellness events. The principles that were followed were voluntarism, individuality, accessibility, relevance, and individualization; different person activating methods (discussions, case analysis, "Mind hedgehog", arguments "Pros and cons", "Brainstorm", learning in groups) were applied as well.

Control group $(C)$ worked according to NFPE programs prepared by teachers and approved by the school principal and school methodical group (see Table 1)

Priorities of the Experimental group were:

- Integral knowledge, training abilities and attitudes.

- Integration of 11-13-year-old children with lower health and physical fitness levels.

- Content that corresponds to 11-13-yearold children's needs, abilities, physical and functional powers.

- Methods and forms that activate and train individual development process.

- Priorities of the Control group were:

- Motor learning and development.

- Training physical skills.

- Training most physically capable children.
- Education content oriented to preparation for competitions (Game "Quadrate", relay race "Brave, strong, quick"; athletics; "Tetrathlon").

In the second stage (academic year 2012-2013) the young adolescents from the same four Klaipeda city comprehensive schools participated in the research. After implementing quasi - experiment in schools, where experimental educational programme was practiced, the curriculum was modified:

- The educational content was oriented towards preparation for competitions. The content only partly corresponded to 11-13-yearold children's needs, abilities, physical and functional powers.

- The content was oriented towards physical skill development. Knowledge transfer and formation of physical abilities were implemented episodically.

- The traditional physical education methods usually applied were classes, group work, team work.

In the control group (C) teachers worked with NFE programme, where the part of activities and given time essentially did not differ from those which were carried out during the quasi-experiment (Table 1).

Data analysis. The data was analysed using the Statistical Package for Social Sciences (SPSS) version 20.0. Descriptive statistics indices were calculated (including means $(M)$ and standard deviation $(S D)$ for each physical development component. Depended $t$ test was used to determine whether the means of two related groups were significantly different. Independent $t$ test was used to examine test differences between two (E and C), (Group I and Group II) groups. For all the tests, statistical significance was set at $p<.05$. 


\section{RESULTS}

The descriptive results are shown in Table 2 and Table 3. Tables provide the means, standard deviation and average values of corresponding age Lithuanian children's physical development. As it can be seen in Table 2, in studies I, II and III the anthropometric indices of the experimental and the control group girls and boys were higher than the average values for Lithuanian schoolchildren. Girls' left handgrip strength in study III and Vital capacity (VC) in all the studies (except group $\mathrm{C}$ in study I), and physiometric indices for both groups boys were lower than the average values for Lithuanian boys in the analysed age groups.
During the second research stage (Table 3) the anthropometrical indices of all of the researched children were higher than the average values for Lithuanian children. Analysing physiometric indices it was determined that group I girls' right handgrip strength and boys' right and left handgrip strength in both groups did not reach the average values in the country.

After study I it was identified that the average results of physical development of male and female groups $\mathrm{E}$ and $\mathrm{C}$ did not reveal significant differences, i.e. groups were homogeneous and met the essential condition - experiment reliability.

Dependent $t$ test indicated that over two academic years E group girls' height, $t(10)=-6.799$,

\begin{tabular}{|c|c|c|c|c|c|c|c|c|c|}
\hline \multirow{3}{*}{ Variable } & \multirow{3}{*}{ Study } & \multicolumn{4}{|c|}{ Girls } & \multicolumn{4}{|c|}{ Boys } \\
\hline & & \multicolumn{2}{|c|}{ E group } & \multicolumn{2}{|c|}{ C group } & & & \multicolumn{2}{|c|}{ C group } \\
\hline & & $\mathbf{M}$ & CD & $\mathbf{M}$ & CD & M & CD & $\mathbf{M}$ & CD \\
\hline \multirow{3}{*}{ Height } & Study 1 & 150.59 & 8.84 & 149.79 & 6.31 & 148.86 & 6.90 & 150.73 & 6.51 \\
\hline & Study 2 & 153.41 & 8.54 & 153.00 & 6.50 & 152.25 & 7.11 & 154.55 & 8.18 \\
\hline & Study 3 & 159.64 & 7.55 & 158.55 & 7.05 & 158.78 & 8.73 & 161.55 & 8.17 \\
\hline \multirow{3}{*}{ Weight } & Study 1 & 45.05 & 6.47 & 40.36 & 6.50 & 44.02 & 16.32 & 39.50 & 7.41 \\
\hline & Study 2 & 46.38 & 6.84 & 42.55 & 7.09 & 47.56 & 16.79 & 42.77 & 8.63 \\
\hline & Study 3 & 50.91 & 5.59 & 49.09 & 7.23 & 50.66 & 19.33 & 47.05 & 8.57 \\
\hline \multirow{3}{*}{ BMI } & Study 1 & 19.90 & 2.65 & 17.93 & 2.07 & 19.51 & 5.06 & 17.32 & 2.10 \\
\hline & Study 2 & 19.69 & 2.22 & 18.11 & 2.35 & 20.20 & 5.05 & 17.75 & 2.14 \\
\hline & Study 3 & 20.01 & 2.12 & 19.56 & 2.94 & 19.78 & 5.56 & 19.90 & 1.89 \\
\hline \multirow{3}{*}{ RHS } & Study 1 & 19.77 & 4.59 & 19.38 & 4.06 & 19.92 & 3.68 & 20.27 & 3.64 \\
\hline & Study 2 & 21.64 & 2.50 & 24.41 & 3.88 & 22.39 & 3.81 & 23.32 & 4.93 \\
\hline & Study 3 & 26.45 & 4.34 & 25.82 & 4.90 & 26.83 & 4.53 & 25.55 & 5.15 \\
\hline \multirow{3}{*}{ LHS } & Study 1 & 17.86 & 4.01 & 18.55 & 5.07 & 18.00 & 3.64 & 19.27 & 3.55 \\
\hline & Study 2 & 20.09 & 3.92 & 22.82 & 3.97 & 21.61 & 3.55 & 21.45 & 4.63 \\
\hline & Study 3 & 23.55 & 3.53 & 23.36 & 5.20 & 24.78 & 4.82 & 24.18 & 4.42 \\
\hline \multirow{3}{*}{$\mathrm{VC}$} & Study 1 & 1990.91 & 359.04 & 2018.18 & 314.84 & 2044.44 & 329.39 & 2022.73 & 371.73 \\
\hline & Study 2 & 2077.27 & 386.24 & 2050.00 & 357.07 & 2130.56 & 416.26 & 2213.64 & 331.73 \\
\hline & Study 3 & 2309.09 & 359.04 & 2090.91 & 383.29 & 2438.89 & 548.94 & 2227.27 & 485.99 \\
\hline
\end{tabular}

Table 2. Physical development indices for 11-13-year-old children of stage $I$ research in the experimental and control groups

Note. RHS $=$ right handgrip strength; LHS $=$ left handgrip strength; $\mathrm{VC}=$ vital capacity. 


\begin{tabular}{|c|c|c|c|c|c|c|c|c|c|}
\hline \multirow{3}{*}{$\begin{array}{l}\text { Table } 3 \text {. Physical develop- } \\
\text { ment indices for 13-year- } \\
\text { old children in stage } \\
\text { II research in groups I } \\
\text { and II }\end{array}$} & \multirow{3}{*}{ Variable } & \multicolumn{4}{|c|}{ Girls } & \multicolumn{4}{|c|}{ Boys } \\
\hline & & \multicolumn{2}{|c|}{ Group I } & \multicolumn{2}{|c|}{ Group II } & \multicolumn{2}{|c|}{ Group I } & \multicolumn{2}{|c|}{ Group II } \\
\hline & & M & CD & M & CD & M & CD & M & CD \\
\hline & Height & 162.15 & 6.87 & 165.08 & 8.43 & 160.85 & 8.55 & 163.12 & 9.48 \\
\hline & Weight & 52.90 & 10.75 & 52.58 & 13.31 & 50.84 & 9.43 & 49.21 & 9.52 \\
\hline & BMI & 20.06 & 3.48 & 19.07 & 3.58 & 19.57 & 2.65 & 18.33 & 2,61 \\
\hline & RHS & 24.58 & 4.07 & 25.58 & 4.10 & 27.17 & 6.79 & 22.33 & 3.20 \\
\hline $\begin{array}{l}\text { Note. RHS }- \text { right } \\
\text { handgrip strength: LHS }\end{array}$ & LHS & 23.32 & 4.07 & 25.08 & 6.24 & 24.08 & 5.85 & 20.56 & 3.09 \\
\hline $\begin{array}{l}\text { Left handgrip strength; } \\
\text { VC- vital capacity. }\end{array}$ & $\mathrm{VC}$ & 2907.89 & 456.51 & 2695.83 & 807.76 & 3145.83 & 694.06 & 2711.11 & 878.13 \\
\hline
\end{tabular}

$p=.000$; weight, $t(10)=-11.474, p=.000$; right handgrip strength, $t(10)=-8.751, p=.000$; left handgrip strength, $t(10)=-5.285, p=.000$ and vital capacity, $t(10)=-5.590, p=.000$ indices increased significantly. The difference between the pre-test (study I) and post-test (study III) BMI was not significant, $t(10)=-0.302, p=.769$. It should be noted that at the beginning of the research $\mathrm{E}$ group girls' BMI rates on average were higher by $2.92 \mathrm{~kg} /$ $\mathrm{m}^{2}$ than the average values of Lithuanian girls of this age. However, during two school years, BMI of this group young adolescents varied occasionally and at the end of research this difference decreased till $1.31 \mathrm{~kg} / \mathrm{m}^{2}$, i.e. height and weight ratio of girls who participated in non-formal physical education in school became more proportional (Figure 2).
Over two academic years indices of $\mathrm{C}$ group girls' height, $t(10)=-9.936, p=.000$; weight, $t(10)=-6.906, p=.000$; BMI, $t(10)=-3.228$, $p=.009$; right handgrip strength, $t(10)=-7.636$, $p=.000$ and left handgrip strength, $t(10)=-4.783$, $p=.001$, differed significant. The results of vital capacity, $t(10)=-0.561, p=.587$ did not change significantly.

Independent $t$ test indicated that in study III children's height in groups $\mathrm{E}$ and $\mathrm{C}, t(20)=0.350$, $p=.730$; weight, $t(20)=0.660, p=.517$; BMI, $t(20)=0.416, p=.682$; right handgrip strength, $t(20)=0.322, p=.750$; left handgrip strength, $t(20)=0.096, p=.925$ did not differ significantly.

Dependent $t$ tests indicated that the difference in height between $\mathrm{E}$ group boys the pre-test
Figure 2. The alternation of $\mathbf{E}$ and $\mathbf{C}$ group girls' BMI indices during two academic years

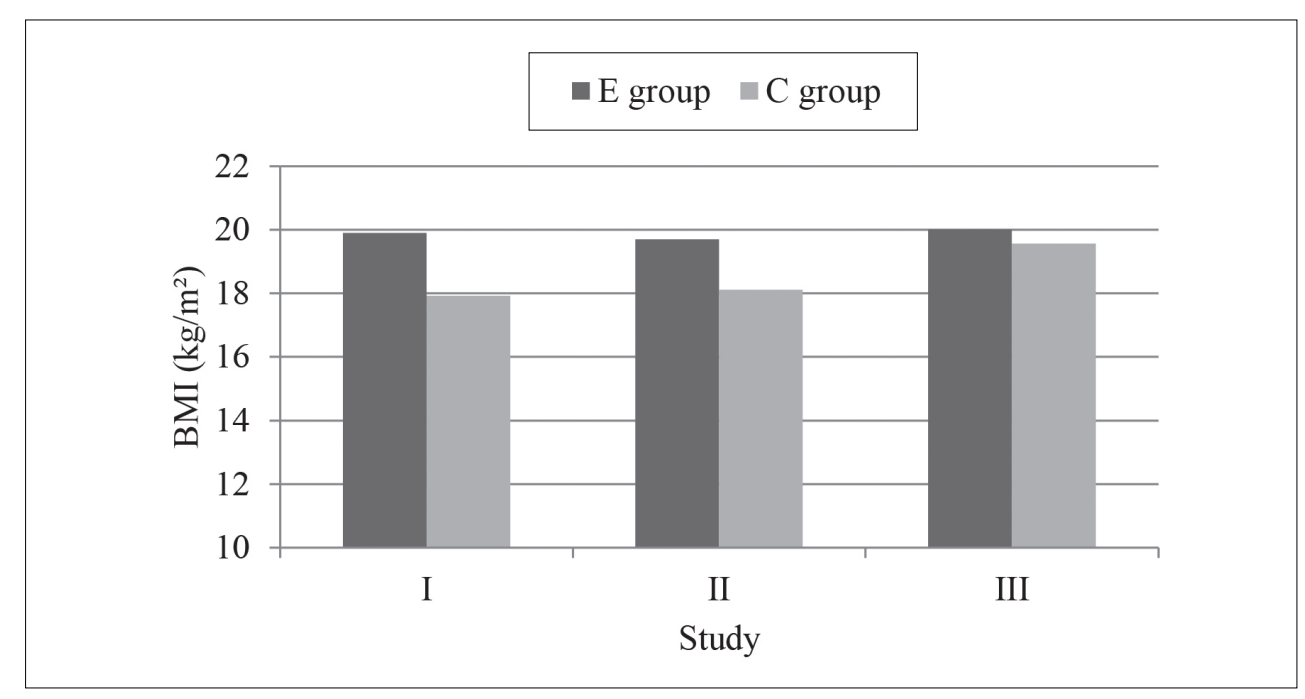




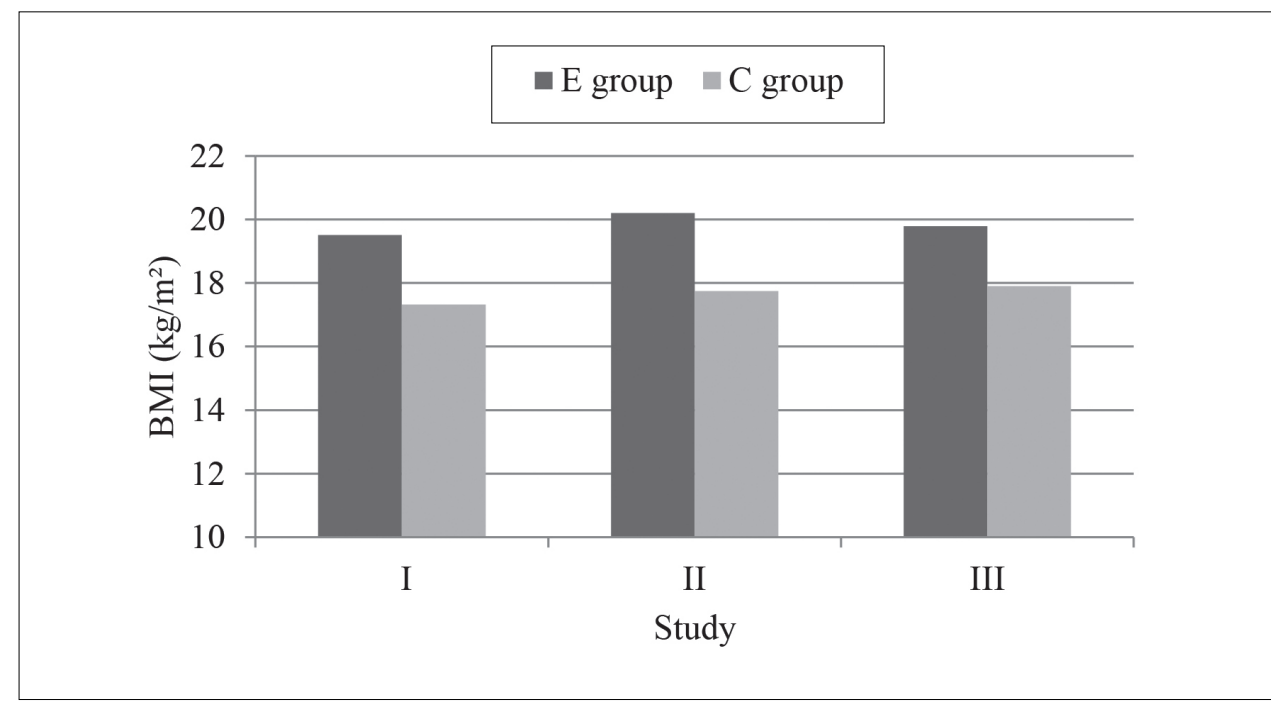

and post-test, $t(17)=-11.386, p=.000$; weight, $t(17)=-5.030, p=.000 ;$ right handgrip strength, $t(17)=-10.276, p=.000$; left handgrip strength, $t(17)=-7.161, p=.000 ;$ vital capacity, $t(17)=-3.864$, $p=.001$ was significant. E group boys', as well as girls' BMI $(t(17)=-0.572, p=.575)$ did not change significantly.

$\mathrm{C}$ groups boys' all tests - height, $t(10)=-8.250$, $p=.000$; weight, $t(10)=-7.965, p=.000$; BMI, $t(10)=-2.308, p=.044$; right handgrip strength, $t(10)=-4.810, p=.001$; left handgrip strength, $t(10)=-4.034, p=.002$ and vital capacity, $t(10)=-3.042, p=.012-$ indices changed significantly.

Independent $t$ test indicated that in study III differences between $\mathrm{E}$ and $\mathrm{C}$ group boys' height, $t(27)=-0.848, p=.404$; weight, $t(27)=0.582$, $p=.497$; BMI, $t(27)=1.076, p=.565$; right handgrip strength, $t(27)=0.706, p=.486$; left handgrip strength, $t(27)=0.333, p=.742$ and vital capacity, $t(27)=1.050, p=.303$ were not significant.

Independent $t$ test revealed that in the research implemented in 2013 group I girls' height, $t(29)=-0.858, p=.398$; weight $t(29)=$ $0.257, p=.799$; BMI, $t(29)=0.889, p=.381$; right handgrip strength, $t(29)=-0.438, p=.665$; left handgrip strength, $t(29)=-0.926, p=.363$ and vital capacity, $t(29)=0.913, p=.369$ did not differ significantly from the values of group II girls.

Group I and group II boys' height, $t(37)=-0.868, p=.391$; weight, $t(37)=0.347$, $p=.730$; BMI, $t(37)=1.363, p=.181$; left handgrip strength, $t(36)=1.712, p=.097$ and vital capacity, $t(36)=1.486, p=.147$ results were also similar.
Right handgrip strength in group I was significantly better than that in group II, $t(36)=2.0314, p=.027$.

\section{DISCUSSION}

This study was conducted to investigate the effect of interventions of non-formal physical education curriculum on physical fitness of 11-13-year-old children. Tutkuvienè (1995) suggests that from all structural and functional condition indicators height is mostly determined by genetic factors. Our research results show that experimental education programme had no influence on children's growth alternation indices: there were no statistically significant differences between the groups, i.e. the rate of growth in all the groups was similar. Baxter-Jones et al. (2008), Erlandson, Sherar, Mirwald, Maffulli, \& BaxterJones (2008) also established that the format and the extent of physical activity had no effect on growth rate.

In the analysis of the indices of height alternation, their quantitative changes are very important in particular years because during the period of rapid growth rate, which is called pubertal growth spurt, the intensive structural and functional changes happen in organs and tissues. The scientists (Armonaitè-Engelmanienè, 2008; Tutkuviene, 2007) point out that Lithuanian girls' pubertal growth spurt is at the age of 11-14 years, that of boys' - at 13-16 years of age, though the height spurt summit, according to the data of Grinienè and Vaitkevičius (2009), for girls is at the age of 11.4-12.2, for boys - 13.4-14.4. 
The research revealed that the height changes of both sexes were bigger in the second year of the research (age 12-13 years): in the sixth grade girls' height averagely increased by $6.26 \mathrm{~cm}$, boys' -6.99 $\mathrm{cm}$. The results of our research were close to the data proposed by Volbekienè and Kavaliauskas (2002), where statistically significant difference $(p<.001)$ was determined between the height of 12 and 13-year-old pupils and of both sexes it is equal -6 centimetres.

The other indicator of development - the weight - is much more labile than height and varies more because of the impact of various factors. The scientists (Cora et al., 2009; Julia et al., 2008; Lowry et al., 2007) emphasize that every year increasingly bigger part of adolescents' weight do not correspond to recommendatory standards. World Health Organization (WHO, 2014) announces that more than 40 million children aged more than five years are overweight or obese, and children's overweight and obesity indices have achieved epidemic extent in many industrial counties.

Analysing the weight indices of young adolescents who participated in the quasiexperiment it was ascertained that experimental and control groups' weight changes in two academic years were statistically significant $(p<.001)$. The weight of group E girls in two years increased by $5.9 \mathrm{~kg}$, though $\mathrm{C}-8.7 \mathrm{~kg}$, for the boys $-\mathrm{E}-6.6 \mathrm{~kg}$, $\mathrm{C}-7.6$ kilograms. After analysing the results, the assumption that participation in NFPE in school had a positive influence to group E girls' weight control can be made: at the beginning of the research the girls' average weight in this group was significantly bigger than the values of country's average weight indices, though at the end of the research they were close to country's average (Tutkuvienè, 1995; Volbekienè \& Kavaliauskas, 2002).

It was determined, that weight changes of young adolescents of both sexes, just like the changes of height, in the sixth grade (12-13 years old) were bigger than in the fifth grade (11-12 years old). At the end of the research the weight indices of subjects were close or slightly exceeded the optimum limits, however it should be noted that the indices of height were also bigger than the country's average indices. Analysing the weight indices it is purposeful to follow BMI which helps to evaluate whether weight matches the height. Tutkuviene and Jakimavičienè (2004) suggest that BMI of 11-12-year-old boys fluctuate a little, though the bigger change occurs at the age of $12-13$ years.
Girls' BMI similarly grows in the first and second years. BMI alternation curves (WHO, 2007) of 5-19-year-old children, offered by WHO, indicate that BMI of 11-13-year-old children gradually increases. Our research shows that during two academic years BMI increased only for group E girls and boys, these differences in $\mathrm{C}$ group were significant $(p<.05)$. The bigger changes of girls' BMI were determined in the second research year, though this index for boys mediates both in the first and the second years.

Carrying out the research after four years, it was determined that BMI indices of subjects were very similar to those in the research performed in 2009. Comparing the results of the first and second groups, statistically significant differences did not show up, $p>.05$.

Physical development in the early adolescence was evaluated by the functional parameters, i.e. $\mathrm{VC}$ and static arm strength. VC index is increasing while a kid grows up (Armonaitè-Engelmanienè, 2008; Malina et al., 2004; Skirius, 2007). This has also been proved by our research data: VC indices of all the young adolescent groups improved. However, these changes were not similar in all the groups and that highlighted the alternation of the effect of the applied measures on VC indices during the pedagogical experiment. For $\mathrm{E}$ group girls and both $(\mathrm{E}$ and $\mathrm{C})$ group boys significant $(p<.05)$ changes were determined in two academic years, but these changes in $\mathrm{E}$ group boys were bigger than in group C: in two experimental years $\mathrm{VC}$ indices of $\mathrm{E}$ group boys increased averagely by $394.45 \mathrm{~cm}^{3}$, though in C group - $204.54 \mathrm{~cm}^{3}$.

Four years later the repeated research also estimated that the $\mathrm{VC}$ indices of first group both sexes were better than those of the second group young adolescents. Considering the scientists' (Malina et al., 2004; Šiupšinskas, Vitaraitè \& Berškienė, 2007; Tutkuvienè, 1995) propositions that this index reflects the physical activity impact on the organism, the assumption can be made that systematically doing aerobic exercises, which were used considering the capacity of individual functional systems, had a positive effect on the alternation of first group's VC indices.

It was ascertained that during the quasiexperiment the static arm strength changes were significant $(p<.01)$ in all the groups. The differences between $\mathrm{E}$ and $\mathrm{C}$ group young adolescents, who constantly participated in NFPE in school, were slight. After repeating the 
research in four years, significant differences of static arm strength indices between the first and the second groups were not determined, $p>.05$. Following the received data, we draw a conclusion that experimental educational programme had no influence on static arm strength changes.

The research has some limitations. First of all, the educational institutions, from which the 11-13-year-old children participated in the quasiexperiment, were selected not at random, but following some criteria. Besides, only a small part of pupils participated in NFPE in school, therefore the samples of groups E and C, Group I and Group II were little. Despite all these limitations, our research revealed that qualitative characteristics of non-formal physical education curriculum are a very important factor for 11-13-year-old children's balanced physical development.

\section{CONCLUSION}

Non-formal physical education curriculum to meet children's hobbies, needs, abilities, physical and functional powers was developed and implemented. It encompassed and integrally developed knowledge, abilities and attitudes; child activating learning methods and forms were applied - all these factors had a positive effect on decreasing 11-13-year-old children's levels of BMI and increasing the levels of VC. These findings provide evidence for the development of effective and feasible curriculum of non-formal physical education at school.

Acknowledgement. We are grateful to the administration of comprehensive schools where the research was carried out and to non-formal education teachers for the conditions to carry out the research. We are grateful to all the children who took part in non-formal education programme.

\section{REFERENCES}

Abernethy, B., Kippers, V., Hanrahan, S. J., Pandy, M. G., McManus, A. M., \& Mackinnon, L. (2013). The biophysical foundations of human movement. Champaign, IL: Human Kinetics.

Armonaitè-Engelmanienè, R. (2008). Brendimas, priežiūros ypatybès. Paaugliu sveikatos priežiūra šeimos gydytojo praktikoje. Kaunas: Vitae Litera.

Baxter-Jones, A. D., Eisenmann, J. C., Mirwald, R. L. Faulkner, R. A., \& Bailey, D. A. (2008). The influence of physical activity on lean mass accrual during adolescence: A longitudinal analysis. Journal of Applied Physiology, 105(2), 734-741. doi: 10.1152/ japplphysiol.00869.2007.

Bouchard, C., \& Katazmarzyk, P. T. (2010). Physical activity and obesity. Champaign, IL: Human Kinetics.

California Department of Education. (2009). California after school physical activity guidelines. Retrieved from http://www.cde.ca.gov/ls/ba/as/documents/ paguidelines.pdf\#search=california $\% 20$ afterschool $\% 20$ physical\%20activity\%20guidelines\&view=FitH\&page mode $=$ none.

Carrel, A. L., Logue, J., Randall, R. C., Clark, R. R., Curtis, V., Montague, P., \& Baldwin, S. (2011). An afterschool exercise program improves fitness, and body composition in elementary school children. Journal of Physical Education and Sports Management, 3, 32-36.

Cora, E., McTigue, K. M., Burke, L. E., Poirier, P., Eckel, R. H., Howard B. V. ... Pi-Sunyer, F. X. (2009). Mortality, health outcomes, and body mass index in the overweight Range. Circulation, 119, 3263-3271. doi: 10.1161/circulationaha.109.192574.
Drake, K. M, Beach, M. L., Longacre, M. R., Mackenzie, T., Titus, L. J., Rundle A. G., \& Dalton, M. A. (2012). Influence of sports, physical education, and active commuting to school on adolescent weight status. Pediatrics, 130(2), 296-304. doi: 10.1542/peds.20112898.

Erlandson, M. C., Sherar. L. B., Mirwald, R. L., Maffulli, N., \& Baxter-Jones, A. D. (2008). Growth and maturation of adolescent female gymnasts, swimmers, and tennis players. Medicine and Science in Sports and Exercise, 40(1), 34-42. doi: 10.1249/ mss.0b013e3181596678.

Gao, Z., Oh, H., \& Shehg, H. (2011). Middle school students' body mass index and physical activity levels in physical education. Research Quarterly for Exercise and Sport, 82(1), 145-150. doi: 10.1080/02701367.2011.10599732.

Grinienè, E., \& Vaitkevičius, J. V. (2009). Vaiku ir paaugliu organizmo sistemogenezè. Šiauliai: Šiaurès Lietuva.

Haberstick, B. C., Lessem, J. M., McQueen, M. B., Boardman, J. D., Hopfer, C. J., Smolen, A., \& Hewitt, J. K. (2010). Stable genes and changing environments: Body mass index across adolescence and young adulthood. Behavior Genetics, 40(4), 495-504. doi: 10.1007/s10519-009-9327-3.

Julia, M., Van Weissenbruch, M. M., Prawirohartono, E. P., Surjono, A., \& Delemarre-van de Waal, H. A. (2008). Tracking for underweight, overweight and obesity from childhood to adolescence: A 5-year follow-up study in urban Indonesian children. Hormone Research, 69, 301306. doi: 10.1159/000114862. 
Lowry, R., Lee, S. M., Galuska, D. A., Fulton, J. E., Barrios, L. C., \& Kann, L. (2007). Physical activityrelated injury and body mass index among us high school students. Journal of Physical Activity and Health, 4, 325-342.

Machado, J. F. V., Fernanndes, P. R., \& Filho, J. F. (2008). Genotypic and environmental influence on physical qualities observed by the method of twins in males. Fitness \& Performance Journal, 7(6), 393-399. doi: 10.3900/fpj.7.6.393.e.

Maes, H. H., Neale, M. C., Medland, S. E., Keller, M. C., Martin, N. G., Heath, A. C., \& Eaves, L. J. (2009). Flexible Mx specification of various extended twin kinship designs. Twin Research and Human Genetics, 12(1), 26-34. doi: 10.1375/twin.12.1.26.

Malina, R. M., Bouchard, C., \& Bar-Or O. (2004). Growth, maturation, and physical activity. Champaign, IL: Human Kinetics.

McArdle, W. D., Katch, F. I., \& Katch, V. L. (2009). Exercise physiology: Energy, nutrition and human performance (sixth ed.). Philadelphia, Md.: Lippincott Williams \& Wilkins.

Raustorp, A. (2010). Eight years secular trends of physical self-esteem among Swedish adolescents. Journal of Physical Activity and Health, 7, 369-374. doi: 10.1515/IJAMH.2010.22.2.237.

Da Silva, L. S, Fisberg, M., de Sousa Pires, M. M, Nassar, S. M., \& Sottovia, C. B. (2013). The effectiveness of a physical activity and nutrition education program in the prevention of overweight in schoolchildren in Criciúma, Brazil. European Journal of Clinical Nutrition, 67(11),1200-1204. doi: 10.1038/ejcn.2013.178.
Skernevičius, J., Raslanas, A., \& Dadelienè, R. (2004). Sporto mokslo tyrimu metodologija. Vilnius: LSIC.

Skirius, J. (2007). Sporto medicina. Kaunas: LKKA.

Šiupšinskas, L., Vitaraitè, A., \& Berškienè, K. (2007). 19-29 metu Lietuvos gyventoju fizinio pajégumo testai.

Lietuvos gyventoju fizinio pajegumo testavimo ir fizines būklès nustatymo metodika. Vilnius: LSIC.

Tutkuvienė, J., \& Jakimavičienė, E. M. (2004). Kūno sudejjimo rodikliai ir jų sąsajos su bendra sveikatos būkle. Theory and Practice in Medicine, 1(37), 59-63.

Tutkuvienè, J. (2007). Lietuviu vaiku auksologine charakteristika: Augimo ir brendimo kriterijai, veiksniai ir epochiniai pokyčiai. Vilnius: Vilniaus universitetas.

Tutkuvienè, J. (1995). Vaiku augimo ir brendimo vertinimas. Vilnius: Meralas.

Vajda, I., Mèszáros, J., Mèszáros, Z. Prókai, A., Sziva, A., Photiou, A., \& Zsidegh, P. (2007). Effects of 3 hours a week of physical activity on body fat and cardiorespiratory parameters in obese boys. Acta Physiologica Hungarica, 94(3), 191-198.

Volbekienè, V., \& Kavaliauskas, S. (Eds). (2002). Eurofitas. Fizinio pajègumo testai, metodika, Lietuvos moksleiviu fizinio pajègumo rezultatai. Vilnius: LSIC.

Wilmore, J. H., \& Costill, D. L. (2004). Physiology of sport and exercise. Champaign, IL: Human Kinetics.

World Health Organization (WHO). (2007). Growth reference data for 5-19 year. Retrieved from http:// www.who.int/growthref/en/.

World Health Organization (WHO). (2014). Obesity and overweight. Retrieved from http://www.who.int/ mediacentre/factsheets/fs311/en/. 